\title{
Analisis Komoditas Basis Hortikultura dan Proyeksi Produksi Di Kabupaten Tabalong
}

\section{(Analysis of The Commodities of The Basis of Horticulture and Production Projection In Tabalong Regency)}

\author{
Ahmad Suhaimi ${ }^{1)}$ \& Naparin ${ }^{2)}$ \\ Program Studi Agribisnis, Sekolah Tinggi Ilmu Pertanian Amuntai \\ 1)ahmad99ec@gmail.com \\ ${ }^{2)}$ naparin@gmail.com
}

\begin{abstract}
ABSTRAK
Penelitian ini bertujuan untuk menentukan komoditas basis hortikultura di Kabupaten Tabalong dan menganalisis proyeksi produksi serta meramalkan hasil produksi dalam 5 tahun yang akan datang. Metode yang digunakan dalam menganalisis data-data yang tersedia dari instansi terakait di pemerintahan Kabuptaen Tabalong adalah metode Analisis Location Qoutient (LQ) dan metode Analisis Trend. Menentukan komoditas basis perkecamatan dilakukan dengan Analisis Location Qoutient (LQ) dari 12 Kecamatan di Kabupaten Tabalong ada 5 Kecamatan yang nilai LQ nya di atas 1. Meramalkan produksi hortikultura dalam 5 tahun yang akan datang di lakukan dengan Analisis Trend berdasarkan hasil analisis dari 5 kecamatan peningkatan jumlah produksi pada tahun 2017 untuk komoditas Cabe Besar sebesar 18,4\% peramalan ke tahun 2021 sebesar 21,6\% dan untuk komoditas tanaman omat pada tahun 2017 jumlah produksi sebesar 17,7\% peramalan ketahun 2021 sebesar 22,3\% angka ini menunjukkan peningkatan jumlah produksi yang besar.
\end{abstract}

Kata Kunci: Analisis, komoditas, basis, hortikultura, produksi.

\section{ABSTRACT}

This study aims to determine the commodity base of horticulture in Tabalong Regency and analyze production projections and forecast production in the next 5 years. The method used in analyzing the data available from related institutions in the government of Tabalong Kabuptaen is the Location Qoutient (LQ) Analysis method and the Trend Analysis method. Determining sub-district base commodities is done by Analysis of Location Qout (LQ) from 12 Subdistricts in Tabalong Regency there are 5 Subdistricts whose $L Q$ values are above 1. Forecasting horticulture production in the next 5 years is done by Trend Analysis based on the results of analysis of 5 sub-districts the amount of production in 2017 for large chili commodities is $18.4 \%$ forecasting in 2021 amounting to $21.6 \%$ and for tomat plants commodities in 2017 the number of production is $17.7 \%$ forecasting in 2021 is $22.3 \%$ this figure indicates an increase in the number large production.

Keywords: Analysis, commodity, basis, horticulture, production.

\section{PENDAHULUAN}

Strategi pembangunan pertanian dapat dikatakan berhasil apabila mampu berkontribusi pada peningkatan kesejahteraanmasyarakat, sehingga tidak semata berorientasipada peningkatan produksi fisik sekian macam komoditas pertanian tanaman pangandan hortikultura, perkebunan, peternakan, dan perikanan. Kriteria keberhasilan itu seharusnya dapat diukur dari perbaikan tingkat pendapatan usahatani (dan pelaku di sektor lain), peningkatan produktivitas tenaga kerja, serta perbaikan indikator makroseperti pengurangan angka kemiskinan dan pengangguran (Arifin, 2010).

Penetapan suatu komoditas sebagai komoditas unggulan daerah harus disesuaikan dengan potensi sumber daya alam dan sumber daya manusia yang dimiliki oleh daerah. Komoditas yang dipilih sebagai komoditas unggulan daerah adalah komoditas yang memiliki produktifitas tinggi 
dan dapat memberikan nilai tambah sehingga berdampak positif bagi kesejahteraan masyarakat. Selain itu penetapan komoditas unggulan daerah juga harus mempertimbangkan kontribusi suatu komoditas terhadap pertumbuhan ekonomi dan aspek pemerataan pembangunan pada suatu daerah (Syahroni, 2005).

Komoditas unggulan hortikultura di Kabupaten Tabalong mencakup buah-buahan seperti durian, langsat, dan rambutan. Untuk sayuran seperti kacang panjang, tomat, cabe dan terong. Untuk tanaman obat-obatan seperti jahe dan lada, sedangkan untuk mata pencaaharian masyarakat pertanian di Kabupten Tabalong masih mengandalkan perkebunan karet yang mana fluktuasi harga bisa sewaktu-waktu turun drastis sehingga memungkinkan komoditas hortikultura sebagai jalan alternatif untuk masyarakat (BPS Tabalong, 2017 \& 2016). Tujuan Penelitian ini adalah (i) mengetahui tingkat produksi komoditas basis hortikultura (ii) mendapatkan komoditas basis hortikultura dalam mencapai kesejahteraan petani (iii) Mengetahui proyeksi produksi hortikultura 5 tahun ke depan di Kabupaten Tabalong.

\section{METODE PENELITIAN}

\section{Tempat dan Waktu Penelitian}

Penelitian ini dilaksanakan di Kabupaten Tabalong Propinsi Kalimantan Selatan. Penelitian ini dilakukan dari bulan April 2017 - Agustus 2017. Persiapan, survei pendahuluan dan terjun ke lapangan (pengambilan data) memerlukan waktu 1 bulan dari bulan April sampai dengan bulan Mei. Penulisan laporan, penggandaan dan seminar pada bulan Agustus sampai dengan September 2017.

\section{Jenis dan Sumber Data.}

Data yang dikumpulkan meliputi data sekunder yang menggunakan data dari tahun 2012-2016 tentang total jumlah produksi komoditas hortikultura di Kabupaten Tabalong dan total jumlah produksi komoditas hortikultura perkecamatan, data tersebut bersumber dari Badan Pusat Statistik (BPS) serta Dinas Pertanian Kabupaten Tabalong.

\section{Metode Pengumpulan Data}

Data yang dikumpulkan dalam penelitian ini adalah data sekunder penelitian ini akan mengidentifikasi dan menganalisis sektor komoditas unggulan/basis hortikultura dalam pengembangan kesejahteraan petani di Kabupaten Tabalong, jenis metode ini adalah jenis yang digunakan untuk pengumpulan data, karena data yang diperlukan berupa data sekunder, yakni berbentuk laporan-laporan yang telah disusun oleh instansi terkait dalam lingkungan pemerintah Kabupaten Tabalong. Demikian pula dengan data-data lainnya yang berupa laporan tertulis.

\section{Metoda (Jenis Penelitian)}

Menurut Nawawi (1993), jenis penelitian yang sesuai dengan pengumpulan data yang berhubungan dengan masalah yang dikemukakan, dilakukan dengan metode penelitian kepustakaan (Liberary Research), yaitu penelitian yang dilakukan terhadap sumber-sumber tertulis berupa literatur, buku, makalah, artikel dan karangankarangan lain. Penulis berusaha mengupas secara konseptual terhadap potensi produksi Hortikultura Kabupaten Tabalong dengan cara melalui data yang ada. Oleh karena itu, penelitian ini akan menggunakan pendekatan kualitatif dengan kajian pustaka, yaitu cara menuliskan, mereduksi dan menyajikan datadata.

\section{Analisis Data}

Menjawab tujuan pertama dan kedua yaitu mengetahui nilai LQ masing-masing kecamatan di Kabupaten Tabalong dan komoditas basis hortikultura di gunakan analisis Location Quotient, maka di lakukan tahapan sebagai berikut:

\section{Insert Data}

Insert data series merupakan subsektor selama lima tahun terakhir dengan format kolom dan angka, kolom diisi dengan nama wilayah, sedangkan baris diisi dengan jumlah produksi yang akan di analisis.

\section{Menghitung Produksi Hortikultura Per Kecamatan}

Komoditas hortikultura rataan produksi setiap kecamatan, setiap rataan 
diberi notasi "Vik". Kemudian jumlahkan nilai rataan total produksi hortikultura ditiaptiap kecamatan. Hasilnya menunjukan jumlah produksi hortikultura tiap kecamatan. Hasil rataan diberi notasi "Vk".

\section{Menjumlahkan Produksi Hortikultura}

Jumlah rataan produksi hortikultura semua wilayah, penjumlahan ini menghasilkan total produksi hortikultura dari wilayah yang diberi notasi "Vip". Kemudian jumlah nilai rataan total produksi hortikultura dari semua wilayah. Hasilnya menunjukan jumlah produksi hortikultura yang selanjutnya diberi notasi "Vp".

\section{Menghitung LQ}

Langkah terakhir dari tahapan ini adalah menghitung nilai LQ, caranya dengan memasukkan notasi-notasi yang telah diperoleh kedalam formula LQ yaitu Vik/Vk sebagai pembilang dan Vip/Vp sebagai penyebut. Metode Location Quotient (LQ) adalah salah satu tehnik pengukuran yang paling terkenal dari model data statistik untuk menentukan komoditas basis hortikultura khusunya sayuran sektor basis dan non basis. Analisis LQ dimaksudkan untuk mengidentifikasi dan merumuskan komposisi pergeseran sektor-sektor basis.

Menjawab tujuan ketiga adalah untuk mengetahui tingkat produksi 5 tahun mendatang dengan menggunakan Analisis trend, yang paling menentukan adalah kualitas keakuratan data dari informasi yang didapat serta waktu dari data-data tersebut, untuk melakukan peramalan pada masa yang akan dating Jumlah nilai $X$ sama dengan 0 $\left(\sum X=0\right)$ memberikan nilai pada urutan waktu (tahun) sehingga jumlah nilainya menjadi $=$ 0 , pemberian nilai $X$ diberikan mulai tengah waktunya. Untuk nilai dimensi genap ada dua waktu berada ditengah-tengah, contoh nilai 1 dan 1 seterusnya hingga hasil $X=0$, untuk nilai dimensi ganjil hanya satu yang berada ditengah-tengah dan langsung diberi 0 .

\section{HASIL DAN PEMBAHASAN}

\section{HASIL}

Tabel 1. Jumlah Persentase Pertumbuhan Produksi

\begin{tabular}{cccccccc}
\hline \multirow{2}{*}{ No } & Tahun & 2012 & 2013 & 2014 & 2015 & 2016 & $\begin{array}{c}\text { Rataan Produksi } \\
(\%)\end{array}$ \\
\hline 1 & Komoditi & & & & & & 277 \\
& Kacang Panjang & 1,796 & 1,973 & 1,126 & 3,580 & 277 & 25,66 \\
\hline 2 & Cabe Besar & 20,5 & 22,5 & 12,8 & 40,9 & 3,16 & 19,94 \\
\hline 3 & $\%$ & 10,7 & 12,1 & 3,30 & 60,2 & 13,4 & 99,99 \\
\hline 3 & Tomat & 1,850 & 826 & 164 & 1,765 & 134 & 19,96 \\
\hline
\end{tabular}

Sumber : Data yang diolah (2017).

Nilai LQ Produksi Hortikultura di Kabupaten Tahun 2012-2016

Untuk mengidentifikasi dan merumuskan komposisi pergeseran sektorsektor basis, dengan dasar rumus: $\mathrm{LQ}=(\mathrm{Vik} / \mathrm{Vk}) /(\mathrm{Vip} / \mathrm{Vp})$
Contoh Perhitungan :

$$
\mathrm{LQ}=\frac{310 / 580}{4510 / 10480}=1,24
$$

Sumber : Data yang diolah (2017)

Tabel 2. Hasil Proyeksi Produksi Hortikultura di Kabupaten Tabalong 


\begin{tabular}{cccccc}
\hline No & Tahun & $\begin{array}{c}\text { Proyeksi Produksi Cabe } \\
\text { Besar (ton) }\end{array}$ & $\begin{array}{c}\text { Proyeksi Produksi } \\
\text { Tomat(ton) }\end{array}$ & $\begin{array}{c}\text { Proyeksi } \\
\text { Pertumbuhan }(\%)\end{array}$ & $\begin{array}{c}\text { Proyeksi } \\
\text { Pertumbuhan (\%) }\end{array}$ \\
\hline 1 & 2017 & 1.592 & 182 & 18,4 & 17,7 \\
2 & 2018 & 1.662 & 193 & 19,2 & 18,8 \\
3 & 2019 & 1.732 & 205 & 20 & 20 \\
4 & 2020 & 1.802 & 216 & 20,8 & 21,1 \\
5 & 2021 & 1.872 & 228 & 21,6 & 22,3 \\
\hline \multicolumn{5}{r}{ Rataan Produksi } \\
\hline
\end{tabular}

Sumber: Data yang diolah (2017).

$$
\begin{aligned}
& \mathrm{Y}=\mathrm{a}+\mathrm{b} \cdot \mathrm{X} \\
& \mathrm{a}=\sum \mathrm{Y} / \mathrm{N} \\
& =6910 / 5 \\
& \mathrm{~b}=\sum \mathrm{XY} / \sum \mathrm{X} 2 \\
& =1382 \\
& =700 / 10 \\
& =70 \\
& 2017=1382+70 \times 3 \\
& 1382+210 \\
& 1592
\end{aligned}
$$

Tabel 3. Hasil Proyeksi Produksi Hortikultura 5 Kecamatan Yang LQ nya $>1$

\begin{tabular}{ccccccc}
\hline No & Kecamatan & 2017 & 2018 & 2019 & 2020 & 2021 \\
\hline 1 & Bintang ara & 45 & 56 & 66 & 77 & 87 \\
2 & Haruai & 182 & 193 & 205 & 216 & 228 \\
3 & Murung Pudak & 171 & 180 & 189 & 198 & 208 \\
4 & Tanjung & 183 & 199 & 214 & 230 & 245 \\
5 & Tanta & 15 & 16 & 17 & 19 & 20 \\
\hline & 596 & 644 & 691 & 740 & 788 \\
\hline Total & & & & & \\
Kontribusi Proyeksi & $37,43 \%$ & $38,75 \%$ & $39,90 \%$ & $41,06 \%$ & $42,09 \%$ \\
$\quad$ Produksi Hortikultura & & & & \\
Kabupaten
\end{tabular}

Sumber: Data Yang Diolah (2017).

Hasil proyeksi produksi hortikultura 5 kecamatan tersebut cukup memberikan kontribusi terhadap masyarakat petani yakni pada tahun 2017 menunjukan 37,43\% dilihat dari angka indeks persentase ini jauh dari setengahnya seiring berjalannya tahun angka persentase ini terus mengalami peningkatan hingga mencapai $42,09 \%$ sampai pada tahun 2021.

\section{Pembahasan}

\section{Analisis Location Qoutient (LQ)}

Berdasarkan nilai LQ pada tabel 2 menunjukkan komoditas Cabe Besar dan Tomat dipilih sebagai komoditas yang penting dikembangkan dalam program pengembangan kesejahteraan petani berbasis hortikultura di Kabupaten Tabalong. Pemilihan ini didasarkan pada pertimbangan bahwa keempat komoditas ini yang lebih terkonsentrasi dan nilai LQ nya lebih dari satu dan berproduksi sepanjang tahun sehingga diharapkan dapat memasok sayuran dalam jumlah yang cukup besar untuk kebutuhan ekonomi petani berbasis hortikultura di Kabupaten.

Hasil dari analisis LQ berdasarkan produksi sayuran seperti pada Tabel, terlihat bahwa sayuran seperti Cabe Besar dan Tomat merupakan sektor basis dalam perekonomian masyarakat pada beberapa Kecamatan di Kabupaten Tabalong. Cabe Besar menjadi sektor basis dalam perekonomian masyarakat di Kabupaten, Cabe Besar menjadi sektor basis di Kecamatan Bintang Ara, Haruai, Murung Pudak, Tanta. Tomat menjadi sektor basis di Kecamatan Murung Pudak, Tanjung dan Tanta dari 12 Kecamatan yang ada di 
Tabalong hanya 5 Kecamatan yang mempunyai sektor basis yaitu Bintang Ara, Haruai, Murung Pudak, Tanjung dan Tanta.

Jumlah Hasil dari 12 kecamatan yang ada di Tabalong hanya 5 kecamatan yang mempunyai sektor basis yaitu Bintang Ara, Haruai, Murung Pudak, Tanjung dan Tanta, dari 5 kecamatan yang merupakan sektor basis terdapat 2 Kecamatan yang memiliki 2 komoditas dengan nilai LQ lebih dari 1 yakni Kecamatan Murung Pudak dan Tanta untuk komoditas tanaman cabe besar dan tomat. Jika mengacu pada nilai LQ tertinggi selama 5 tahun berturut-turut maka kecamatan Tanta paling tinggi nilai LQ nya yaitu 2012 LQ 2,98, 2013 LQ 5,15, LQ 2014 2,39, 2015 LQ 2,62, 2016 LQ 1,71.

\section{Analisis Trend}

Perhitungan proyeksi produksi dengan menggunakan Analisis Trend suatu metode yang ditujukan melakukan suatu penacacahan atau hipotesa pada masa yang akan datang.

Hasil pendugaan proyeksi produksi hortikultura Kabupaten dari tahun 2017 sampai dengan tahun 2021 mengalami peningkatan pada tahun tahun 2017 tingkat proyeksi pertumbuhan terendah produksi Cabe Besar sebesar 18,4\% dengan produksi 1.592 ton dengan proyeksi pertumbuhan produksi tetinggi pada tahun 2021 sebesar $21,6 \%$ dengan proyeksi produksi 1.872 ton dengan rataan proyeksi produksi sebesar $20 \%$ jumlah ini terus mengalami peningkatan, untuk tanaman tomat mengalami peningkatan dengan rataan proyeksi $20 \%$ dengan total produksi pada tahun 2017 sebesar 152 ton dengan proyeksi pertumbuhan $17,7 \%$, pada tahun 2021 dengan total produksi sebesar 228 ton dengan proyeksi pertumbuhan $22,3 \%$.

Berdasarkan penelitian 5 kecamatan yang LQ nya lebih dari 1 telah dihitung proyeksi produksi kemudian hasil proyeksi produksi 5 kecamatan tersebut dijumlahkan dan dihitung persentase kontribusi antara komoditas basis kecamatan dengan komoditas basis kabupaten, untuk tahun 2017 total proyeksi 5 kecamatan tersebut adalah 596 ton dengan persentase $37,43 \%$ dari 1.592 ton proyeksi Kabupaten, tahun 2018 dengan
644 ton dengan persentase $38,75 \%$ dari 1.662 ton proyeksi Kabupaten, 2019 dengan 691 ton dengan persentase 39,90\% dari 1.732 ton proyeksi Kabupaten, 2020 dengan 740 ton dengan persentase $41,06 \%$ dari 1.802 ton proyeksi Kabupaten, 2021 dengan 788 ton dengan persentase $42,09 \%$ dari 1.872 ton proyeksi Kabupaten.

Proyeksi produksi hortikultura 5 kecamatan tersebut cukup memberikan kontribusi terhadap masyarakat petani yakni pada tahun 2017 menunjukan 37,43\% dilihat dari angka indeks persentase ini jauh dari setengahnya seiring berjalannya tahun angka persentase ini terus mengalami peningkatan hingga mencapai $42,09 \%$ sampai pada tahun 2021.

\section{KESIMPULAN}

Hasil dari 12 kecamatan yang diteliti ada 5 kecamatan yang menunjukkan nilai LQ lebih dari 1 selama 5 tahun berturut-turut adalah tanaman cabe besar yang mana LQ nya lebih dari 1 , disusul tanaman tomat di Kecamatan Tanjung, Murung Pudak dan Tanta yang LQ nya lebih dari 1 selama 5 tahun berturut-turut. Jika mengacu pada nilai LQ tertinggi selama 5 tahun berturut-turut maka Kecamatan Tanta yang paling tinggi nilai LQ nya yaitu 2012 LQ 2,88, 2013 LQ 5,15, LQ 2014 2,32, 2015 LQ 2,21, 2016 LQ 1,53 untuk komoditas tanaman cabe besar.

Proyeksi produksi hortikultura di Kabupaten Tabalong untuk tanaman cabe besar 5 tahun ke depannya yaitu untuk tahun 2017 produksi 1.592 ton dengan pertumbuhan $18,4 \%$ dari tahun sebelumnya, proyeksi tahun 2018 sebesar 1.662 ton dengan pertumbuhan $19,2 \%$ dari tahun sebelumnya, proyeksi tahun 2019 sebesar 1.732 ton dengan pertumbuhan $20 \%$ dari tahun sebelumnya, proyeksi tahun 2020 sebesar 1.802 ton dengan pertumbuhan $20,8 \%$ dari tahun sebelumnya, proyeksi tahun 2021 sebesar 1.872 ton dengan pertumbuhan $21,6 \%$ dari tahun sebelumnya, pendugaan untuk produksi hortikultura jenis sayuran tomat 5 tahun ke depannya yaitu untuk tahun 2017 produksi 182 ton dengan pertumbuhan $17,7 \%$ dari tahun sebelumnya, proyeksi tahun 2018 sebesar 193 ton dengan pertumbuhan 
$18,8 \%$ dari tahun sebelumnya, proyeksi tahun 2019 sebesar 205 dengan pertumbuhan $20 \%$ dari tahun sebelumnya, proyeksi tahun 2020 sebesar 216 ton dengan pertumbuhan 20,8\% dari tahun sebelumnya, proyeksi tahun 2021 sebesar228 ton dengan pertumbuhan $22,3 \%$ dari tahun sebelumnya.

Proyeksi produksi hortikultura 5 kecamatan yang LQ nya lebih dari 1 telah dihitung proyeksi produksi kemudian hasil proyeksi produksi 5 kecamatan tersebut dijumlahkan dan dihitung persentase kontribusi antara komoditas basis kecamatan dengan komoditas basis kabupaten, untuk tahun 2017 total proyeksi 5 kecamatan tersebut adalah 596 ton dengan persentase $37,43 \%$ dari 1.592 ton proyeksi kabupaten, tahun 2018 dengan 644 ton dengan persentase $38,75 \%$ dari 1.662 ton proyeksi kabupaten, 2019 dengan 691 ton dengan persentase $39,90 \%$ dari 1.732 ton proyeksi kabupaten, 2020 dengan 740 ton dengan persentase $41,06 \%$ dari 1.802 ton proyeksi Kabupaten, 2021 dengan 788 ton dengan persentase $42,09 \%$ dari 1.872 ton proyeksi kabupaten.

\section{DAFTAR PUSTAKA}

Arifin, B. 2010. Pembangunan Pertanian Paradigma Kebijakan dan Stategi Revitalisasi. Jakarta: PT Grasindo.

Nawawi, H. 1993. Metode Penelitian Bidang Sosial. Gadjah Mada Erlangga. Yogyakarta

BPS Tabalong. 2017. Luas Panen, Produksi dan Rata-rata produksi Tanaman Hortikultura Tahun 2011-2015. Badan Pusat Statistik Tabalong. Tanjung.

BPS Tabalong. 2017. Kabupaten Tabalong Dalam Angka 2016. Badan Pusat Statistik Tabalong. Tanjung.

Syahroni, M. 2005. Analisis strategi pengembangan komoditas unggulan agribisnis di Kabupaten Dompu Provinsi Nusa Tenggara Barat.Tesis S-2 Program Pasca Sarjana Manajemen dan Bisnis IPB. Bogor. 